\title{
The Effect of Sector Economic Growth on the Performance of Employment and Welfare of People
}

\author{
Nahu Daud ${ }^{1}$ \\ ${ }^{1}$ Faculty of Economics, Khairun University, Ternate, Indonesia \\ Correspondence: Priyono, Graduate Program Master of Management, University Bina Darma, Palembang, \\ Indonesia. Tel: 0812-1697-4878. E-mail: priyono.unu_sidoarjo@yahoo.com
}

Received: June 1, 2017

Accepted: July 20, 2017

Online Published: August 12, 2017

doi:10.5539/ijbm.v12n9p194

URL: https://doi.org/10.5539/ijbm.v12n9p194

\begin{abstract}
The purpose of this study was to analyze the effect of sectorial economic growth on labor absorption, analyze the effect of economic growth on the welfare of society, analysis the influence of labor absorption on community welfare.

The analysis technique used in this research is path analysis. This analysis was developed as a method to study the effect directly or indirectly from independent variable to dependent variable.

The results showed that the growth of the primary sector, and the secondary directly affect the absorption of labor, while the service sector has no effect on the absorption of labor. Then the growth of the secondary sector and the service sector directly affects the welfare of the community and indirectly affect the welfare of the people through the absorption of labor.
\end{abstract}

Keywords: sectorial economic growth, labor absorption and human development index

\section{Introduction}

Economic development as a process in which interconnectedness and mutual influence between the factors that lead to the occurrence of economic development can be identified and analyzed carefully. In this way, it can be seen that the emergence of events that will bring about an increase in economic activity and the level of community welfare from one stage of development to the next stage of development.

The economic development benchmarks should also be supported by social indicators such as literacy rate, education level, health service quality, adequacy of housing needs and so on. In connection with that thought, then in 1990, the United Nations Development Program (UNDP) introduced a development concept called Human Development. This concept prioritizes the achievement of development goals that make people as the focus of development (Human Centered Development). The achievement of these objectives can be measured by indicators of the Human Development Index.

George and Oseni (2012); Ezie (2012) and Ede, Ndubisi, and Nwankwo (2013), identified unemployment as one of the main challenges facing economic development. The threat of unemployment now and in the past has been a major concern for economists, policymakers, economic managers, individuals, governments and many other companies (Bello, 2003). The earliest notions of this economic issue did not escape giving a central point of reflection on unemployment (Njoku \& Ihugba, 2011). Unemployment is defined as a situation where people who are willing and able to work are unable to find a suitable paid job (Fajana, 2000). The same author goes so far as to say that, the higher the unemployment rate in the economy, the higher the poverty and related welfare challenges

From the theoretical side, much controversy over whether the rate of output growth is influenced by demand-side factors in the short term because wage contracts and asymmetric information extend adjustments to long-run equilibrium as studied by Driffill and Schultz (1992), regardless of unanimity among economists about The role of supply-side factors such as physical and human capital and technology to growth over the long term.

In line with that idea, the empirical study conducted by Walterskirchen (1999) states there is no negative relationship between economic growth and unemployment, as GDP and unemployment both increase in the long term. It is clear that jobs will only increase if GDP rises faster than productivity. Another thing that is equal, the 
greater the amount of goods and services produced, the greater the labor required for production; because economic growth and employment go hand in hand. But there is also the notion that higher productivity can mean less work. According to Calmfors and Holmlund (2000) there is often a failure to distinguish between output increases caused by higher capacity utilization and that caused by long-term growth. Labor market reforms suggest that lower wage costs and increased employment of course will cause output to grow during the adjustment process (Njoku \& Ihugba, 2011).

Mardiasmo (2004a, p. 221) argues that regional development is an integrated effort that combines several policy dimensions of all sectors. The goal is to realize a society that is peaceful, democratic, fair, competitive, advanced and prosperous. Then it is also explained that uneven development, as it has been done so far, only prioritizes economic growth and is not balanced with the improvement of social life and the welfare of the people.

As the purpose of national development, regional development also aims at the prosperity of society. Regional economic development is defined as a process of managing existing resources and establishing a partnership pattern between local governments and the private sector to create new jobs and stimulate the development of economic activities in the region (Arsyad, 1999)

The development of economic activity of a region can be seen from the Gross Regional Domestic Revenue (PDRB), which is believed to be one of the main indicators used to measure the success of economic development. However, on the other hand, UNDP proposes a better perceived indicator to measure the success of development, Human Development Index (HDI). To find out the extent to which the HDI and economic development, especially economic development in North Maluku, in Figure 1 below shows the figures GRDP, GRDP per capita, and HDI.

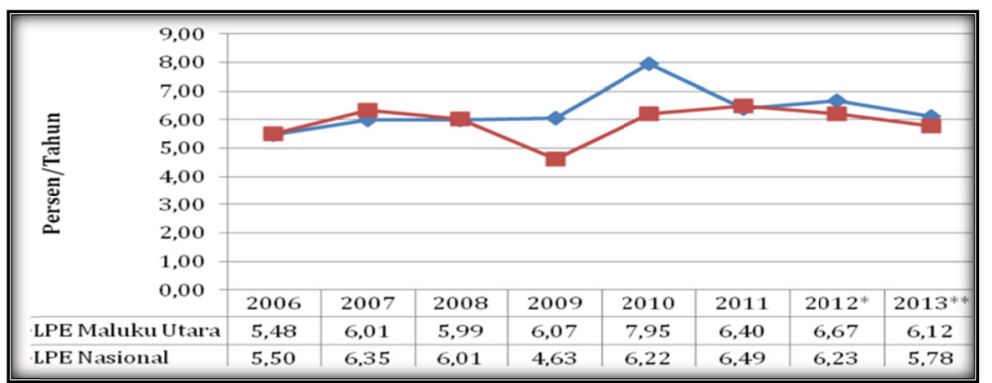

Figure 1. The Economic Growth of the National Maluku Year Period 2006-2013

Source: Central Bureau of Statistics of North Maluku (processed).

\section{Research Methods}

\subsection{Research Sites}

The location of this research was conducted in North Maluku Province, with research time for 6 months. The basis of consideration of the chosen location of this study is based on consideration; First, since the expansion of North Maluku Province in 2009 until now, there has been no specific research related to economic growth towards the absorption of manpower and community welfare.

\subsection{Types and Data Sources}

The type of data used in this study is the type of secondary data (Library research) in the form of time series data period 2006 - 2014. Secondary data associated with this study obtained from the Central Bureau of Statistics of North Maluku Province, Regional planning agency North Maluku As well as other relevant agencies.

\subsection{Method of Collecting Data}

In relation to the types and sources of data, the method used in this data collection is through written documents or electronic from institutions or institutions that is secondary data (Library Research) in the form of time series data from 2006 to 2014. With this method, the data are collected by reviewing the periodic or annual reports prepared by the particular office or agency that are the source of the data used. The data collected include:

1). Employment development

2). The development of Sectoral economic growth 
3). The development of employment in the economic sector.

4). Development of human development index

5). Gross Regional Domestic Product

6). Other data related to this research

\subsection{Analysis Technique}

The analysis technique used in this research is path analysis. This analysis was developed as a method to study the effect (effect) directly or indirectly from independent variable to dependent variable. This analysis is one option in order to study the dependence of a number of variables within the model. Path analysis is also used to examine the relationship between causal models that have been formulated by researchers on the basis of theoretical considerations.

The development model in this research as has been disclosed in the purpose of research is to test the effect of economic growth on employment and the welfare of society. The path diagram model can also be expressed by the equation, thus forming the system of equations. The system of equations is called a system of simultaneous equations, or also often called a structural model.

$$
\begin{gathered}
\mathrm{Y}_{1}=\mathrm{P}_{1} \mathrm{X}+\varepsilon_{1} \\
\mathrm{Y}_{2}=\mathrm{P}_{2} \mathrm{X}+\mathrm{P}_{3} \mathrm{Y}_{1}+\varepsilon_{2}
\end{gathered}
$$

Information:

$\mathrm{Y} 1$ is the absorption of Labor

$\mathrm{Y} 2$ is the people's welfare

$\mathrm{X}$ is economic growth

$\mathrm{P} 1$ to $\mathrm{P} 3$ is the path coefficient

$\mathrm{E} 1 \mathrm{~s} / \mathrm{d}$ e3 is an error

\section{Results and Discussion}

\subsection{Analysis Results}

The result of statistical analysis (see appendix of table 1) shows Normality Test is intended to determine whether research variables are normally distributed or not. Normality test is also useful to see whether the regression model used is good or not. A good regression model is to have a normal or near-normal distribution. Based on Figure 2 it turns out that this model has shown that the residual plot is close to a straight line, so it is assumed that the normality assumption on the model has been fulfilled.
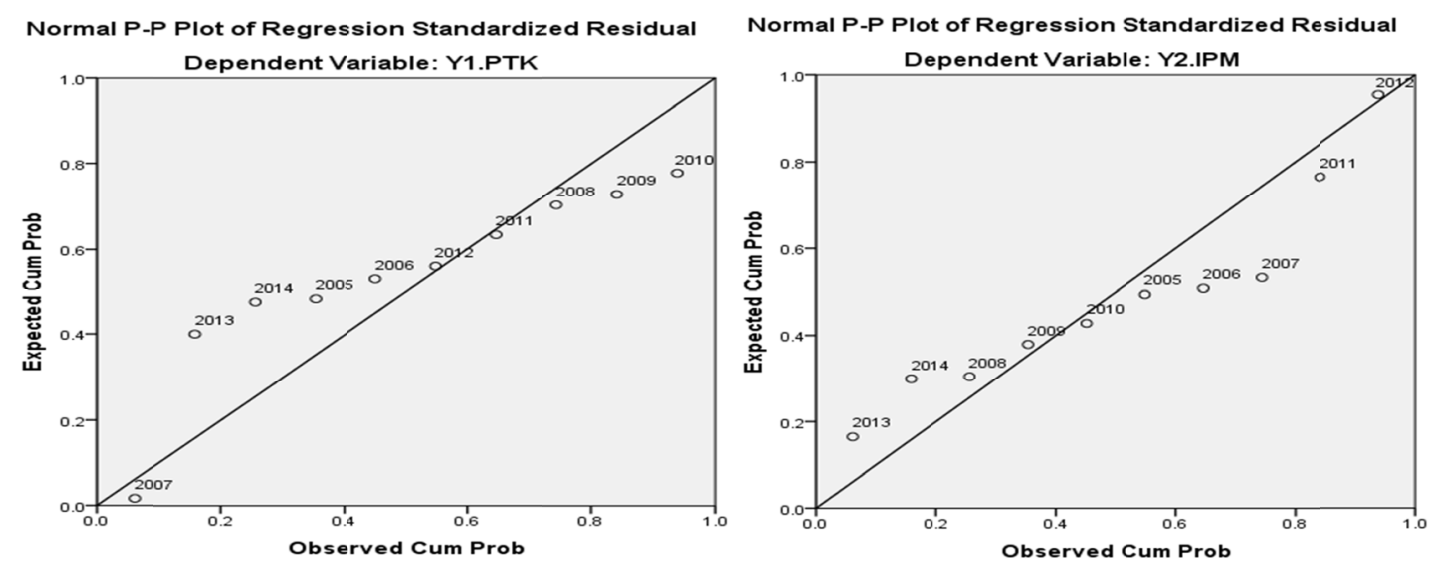

Figure 2. Checking normality assumption on model

\subsection{Multicollinearity Test}

The multicollinearity test is performed by detection of $\mathrm{R} 2$ values and the significance of the variables used. Rule of Thumb says that if a high coefficient of determination (R2) is obtained while most or all variables are partially insignificant, then multicollinearity is suspected in the model (Gujarati, 2004). Moreover, multicollinearity 
usually occurs in the estimation Using time series data so as to combine existing data with cross section data resulting in multicollinearity problem technically can be reduced.

Table 1. Test results VF test hypothesis I coefficients

\begin{tabular}{|c|c|c|c|c|c|c|}
\hline \multirow[b]{3}{*}{ Model } & & \multicolumn{5}{|c|}{ Standardized } \\
\hline & & \multicolumn{2}{|c|}{ Unstandardized Coefficients } & \multirow{2}{*}{$\begin{array}{l}\text { Coefficients } \\
\text { Beta }\end{array}$} & \multicolumn{2}{|c|}{ Collinearity Statistics } \\
\hline & & $\mathrm{B}$ & Std. Error & & Tolerance & VIF \\
\hline \multirow[t]{4}{*}{1} & (Constant) & 7.969 & 3.184 & & & \\
\hline & $\mathrm{X} 1$ & .692 & .357 & .725 & .115 & 8.660 \\
\hline & $\mathrm{X} 2$ & -1.651 & .729 & -.574 & .251 & 3.989 \\
\hline & $\mathrm{X} 3$ & .743 & .532 & .420 & .179 & 5.602 \\
\hline
\end{tabular}

a. Dependent Variable: Y1.

Table 2. Test results VIF test hypotheses II coefficients

\begin{tabular}{cllllll}
\hline & \multicolumn{2}{c}{ Unstandardized } & \multicolumn{2}{l}{ Standardized } & \multicolumn{2}{l}{ Collinearity Statistics } \\
\multicolumn{1}{c}{ Coefficients } & & \multicolumn{2}{l}{ Coefficients } & \multicolumn{2}{l}{ Tolerance } & VIF \\
\hline 1 & B & Std. Error & Beta & & \\
& (Constant) & 17.236 & .662 & & .103 & 9.681 \\
X1 & -.002 & .072 & -.012 & .216 & 4.628 \\
X2 & .512 & .149 & 1.023 & .168 & 5.944 \\
X3 & .304 & .104 & .985 & .515 & 1.943 \\
Y1 & .066 & .034 & .378 & & \\
\hline
\end{tabular}

b. Dependent Variable: Y2

Table 3. VIF test results hypothesis III

\begin{tabular}{|c|c|c|c|c|c|c|}
\hline \multicolumn{7}{|c|}{ Coefficients $^{\mathrm{a}}$} \\
\hline & & \multirow{2}{*}{\multicolumn{2}{|c|}{$\begin{array}{l}\text { Unstandardized } \\
\text { Coefficients }\end{array}$}} & \multirow{2}{*}{\multicolumn{3}{|c|}{$\begin{array}{l}\text { Standardized } \\
\text { Coefficients }\end{array}$}} \\
\hline & & & & & Collinearity & istics \\
\hline \multicolumn{2}{|c|}{ Model } & $\mathrm{B}$ & Std. Error & Beta & Tolerance & VIF \\
\hline \multirow[t]{2}{*}{1} & (Constant) & 16.328 & .472 & & & \\
\hline & Y1 & .194 & .087 & .387 & .854 & 1.171 \\
\hline
\end{tabular}

c. Dependent Variable: Y2

Basic decision-making test Normality of data in this study is to use the ratio of skewness and quortis ratio. As a guideline when the quortical and skewness ratios are between -2 and +2 , then the data distribution is normal (Ghozali, 2011). Table 4.1 shows that the VIF tolerance value of the independent variables in this study is valued from 10 to 20, therefore it can be concluded that in this model there is no multicolliniearity problem. VIF values of less than 10 to 20 are said to have non-serious multicollinearity, and VIF values over 20 are said to have serious multicollinearity.

\section{Discussion of Research Results}

\subsection{The Indirect Effect of the Primary Sector on the Human Development Index}

Through Employment Absorption.

From the analysis it appears that the primary sector has no negative correlation between the sectoral economic improvement of employment in North Maluku Province, which shows the decrease of labor absorption due to growth in the primary sector which is not unidirectional. If the output produced increases, then the number of people employed also increases. This can be attributed to the concept of function in the economic sector, which states that output increases can be achieved if inputs (labor) are increased in growth. Economic sector will affect the level of output (increased employment).

The findings above are in line with his research Sobita (2014) which shows that the independent variable of real GRDP and the price of capital in agriculture, significantly positively affect the employment absorption. The increase of real GRDP and Capital in agriculture, will increase employment. Meanwhile, real wage variable significantly negatively affect labor absorption. An increase in real wages will decrease employment. Similar 
results were found in studies conducted Sulistiawati (2012) that wages have a significant effect and have a negative relationship to employment.

The results of this study reinforce Citra's (2015) study in Aceh that the primary sector indicates the value of intercept (a) and the positive slope (b) value. This means that every 1 percent increase in labor leads to an increase in the primary sector's role in the GRDP structure by 0.66 percent. In economic terms, there are two types of agriculture in place. First, the pattern of agriculture in developed countries that have high efficiency with high production capacity and output ratio per worker. So with a small number of farmers can provide a large output. The second pattern, the agricultural pattern is not or less efficient. The level of productivity is so low. North Maluku Province belongs to the second pattern.

\subsection{The Indirect Effect of Secondary Sector on Human Development Index}

Through Employment Absorption.

The Secondary Sector consists of manufacturing business fields, electricity, gas and water supply, and buildings. The role of the secondary sector in creating national income has not changed significantly and the changes are not consistent in nature. The results of research related to Indirect Effect of Secondary Sector on Human Development Index through Labor Absorption shows positive relationship. This shows that the secondary sector (X1) has a positive relationship and has a significant effect on the human development index (Y2) through employment (Y1) in North Maluku Province. There is an effect of the secondary sector on the absorption of unionized labor, as the economic growth of the real sector through the construction, trade, transport and communications sector output, which is significant to the employment absorption, the more labor can be absorbed. Conversely, a decrease in the secondary sector would reduce labor absorption.

The results of this study are in line with the findings of Imagery (2015) that the workforce in the secondary sector has the smallest share in the total number of people aged 15 years and over who worked. By absorbing 10.16 percent of labor and contributing to GRDP by 20.29 percent in 2013, the secondary sector is the least productive sector in both employment and in its role in the economy of Aceh.

Strong economic structure in economic development can be realized with the balance and ideal harmony between various sectors. Distribution of GRDP according to the field of business shows the size of the economic structure and the role of each sector according to the field of business within a region.

The Indirect Effect of Secondary Sector on Human Development Index through Employment Absorption, in this study also proved to be insignificant, also reinforced previous research from Lapian (2013) in North Sulawesi, that the variable of human development index on employment does not have a significant effect. This means that an increase in the human development index will be followed by an increase in employment with the assumption that other factors affecting the size of the human development index are considered constant. This result suggests that the human development index is important for increasing employment opportunities.

Tambunan (2003) generally describes changes in economic structure experienced by almost all regions. The existence of structural changes of a region / region can be observed based on the aspect of the distribution of employment opportunities by sector. The industrial sector is considered as one of the sectors that can prosper the community and also can overcome the problem of occupation that is less desirable in the agricultural sector, but to support a strong industry must be supported by a tough agricultural sector.

Changes in economic structure resulted in changes in the composition of the business field over its share of gross domestic product over a period of time. There are two perspectives on economic structure, the first distribution of the sectoral gross national product, the second distribution or the total distribution of output by economic sectors. From the demand side, these two views are related to one another, with changes in the structure of the gross national product will cause a change in the total output structure, but the total structural change in output can also be caused by technological change (Sulistyaningsih, 1997).

The above explanation can be understood that changes in economic structure, provide a good enough space for the improvement of IMP through the opening of employment opportunities. The main objectives of economic development efforts besides creating the highest economic growth, should also reduce poverty, income inequality, and unemployment rates. Employment opportunities for residents or communities will provide income to meet the needs of his life.

\subsection{The Indirect Effect of the Tertiary Sector on the Human Development Index}

Through Employment Absorption.

The number of people working depends on the amount of demand or demand in the community. The demand is 
influenced by economic activity and wage rates. The process of placement or employment relationship through the supply and demand of labor is called the labor market. The number of placements (number of people employed or the level of employment) is influenced by the power factor of supply and demand.

The results showed a positive and significant relationship in explaining the changes of labor absorption. This shows that the tertiary sector has a linear relationship with the index of human development through employment in North Maluku Province. Besides, the influence of the tertiary sector on the absorption of manpower in the same direction, as the growth of the real sector through the output of banking, finance and other services sectors has an effect on the increase of labor absorption so that $1 \%$ of tertiary sector growth will increase employment, The rate of growth of the tertiary sector, the more labor that can be absorbed, the decrease in the tertiary sector will reduce the employment.

According to Kuncoro (1997) development is a process whereby a country's per capita income increases over a long period of time with the record that the number of people living below the absolute poverty line does not increase and the income distribution is not increasingly unbalanced. The development process requires economic growth followed by changes in economic structure from agriculture to industry or services and institutions through regulation and institutional reform itself.

The existence of structural changes can be reflected in the role of sectors in the formation of national production and the percentage of labor in each sector of the economy. Where the role or contribution of the primary sector (agriculture and mining) in the formation of Gross Domestic Product (GDP) or Gross Regional Domestic Product (GRDP) will decrease while the role of secondary sector (manufacturing industry, construction) and tertiary sector (services) will increasingly Increased, with the growing state of the economy. Besides, the higher the per capita income of a country, the smaller the role of agriculture in providing and absorbing employment and the industry sector will become more important and increase its role in accommodating the workforce (Kuncoro, 1997).

Economic development in the long-term period following the growth of national income will bring about a fundamental change in the economic structure of the traditional economy with agriculture as a primary sector to the modern sector dominated by non-primer sectors, especially manufacturing industries with increasing retracs to scale (positive relation between output growth and Growth of productivity) as the main engine of economic growth according to Weiss in Tambunan (2001), so there is a positive correlation between economic growth with changes in economic structure through the increase of people's income (demand side effect).

The economic structure will change in the process of economic development. A.G.B. Fisher in Sukirno (2007) has argued that different countries can be distinguished by the percentage of workers employed in the primary, secondary and tertiary sectors. The data it collects shows that the higher per capita income of a country, the less the role of the agricultural sector in providing employment opportunities, while the industrial sector will be increasingly important in the role of employment.

The above explanation is reinforced by Kuznets' theoretical argument in Sukirno (2002) to draw conclusions about the shifting nature of the contribution of various sectors to economic development in 13 countries: England, France, Germany, the Netherlands, Denmark, Norway, Sweden, Italy, USA, Canada, Australia, Japan and Russia. The conclusion obtained is that the contribution of the agricultural sector to national production has declined in twelve out of thirteen countries. Generally at the beginning of economic development, the role of the sector approaches halfway and occasionally reaches up to two-thirds of all national production.

The only exception to this situation is the change occurring in Australia, within eight decades the role of the agricultural sector is growing, although in the course of that period the economic progress is ongoing. In twelve countries the role of the industrial sector in producing national production is increasing, except for Australia. The contribution of the service sector in creating national income has not changed significantly and the changes are not consistent in nature. Generally, the decline of the agricultural sector in creating national production is offset by an increase of almost as much as the role of the industrial sector. This causes the role of the service sector has not changed significantly.

The conclusion of Kuznets' paper is that the production of the agricultural sector is progressing more slowly than the development of national production; The rate of increase of industrial sector production is faster than the rate of national production increase; The absence of a change in the role of the service sector in the national production means that the level of development of the service sector is equal to the level of national production development. There are several factors that drive changes in the economic structure of a country, among others, caused by human nature in consumption activities, The elasticity of demand caused by income elasticity of demand is low for food consumption. While the demand for clothing materials, housing and consumer goods 
industry consumption is the opposite. This means that the pattern of change that occurs following the pattern of income change society, which indicates a welfare improvement (IMP). This direction of improvement reinforces the positively indirect effect of improving the quality of human development in North Maluku Province through the absorption of tertiary sector workers, in line with the theory and results of previous research by Suhartono (2011) which explains the potential sectors to be developed in Central Java Province. Those sectors are agriculture, livestock, forestry and fishery, mining and quarrying, electricity, gas and water, communications and transportation, financial sector, leasing and banking services and services sector. Shift share analysis results that in cities in the province of Central Java there has been a shift or change in economic structure from the primary sector to the tertiary sector.

\subsection{The Direct Influence of Labor Absorption on Human Development Index}

Manpower Absorption in North Maluku Province has a positive impact on the human development index for the period of 2005 - 2014. Due to the influence of the absorption of employment positively and significantly so that if there is an increase in the absorption of labor power will cause growth in the human development index in North Maluku Province. The concept of human development, Todaro (2003), mentions that human development is at the core of a country's development, which plays a major role in shaping the country in absorbing inputs, especially the development of the economic sector. Therefore, qualified human resources are a requirement in the process of economic development (Sjafi'i and Hidayat, 2009). Data from the Central Bureau of Statistics (BPS) shows the rate of employment growth. Compared to the previous year, the absorption rate of workers has decreased, especially in the manufacturing industry sector by 3.82 percent.

Employment data in districts / municipalities in North Maluku Province from 2005-2014 show that growth continues to increase, especially secondary sectors as dominant directors, and have links with other sectors, such as primary sector and tertiary sector. According to Law Number 13 Year 2003 concerning Manpower, Manpower is any person who can do work to produce goods and or services, either to meet their own needs and for the community. Labor may also be defined as working-age population (aged 15-64), or the total number of people in a country that can produce goods and services if there is demand for their labor, and if they are willing to participate in the activity.

The results of this study are in line with Triana's (2014) study, that the variables for human development index (HDI) and percentage of inflation rate indicate positive signs and have a significant effect on regional minimum wage (UMR) by province in Indonesia in the period 2008 to 2012. Singh 2012) finds that there is an effect of the Human Development Index (HDI) and the growth of incomes per capita to poverty in 15 Indian states. Using a correlation and regression analysis tool, the results show that the human development index, and per capita income have a significant effect on poverty reduction in 15 states in India. Further research conducted by Dewi (2014), in his research found that regional minimum wages have a positive and significant influence on the development index People of Central Java.

Sukmaraga (2011), in his research indicates that Human Development Index (HDI) variable has a negative and significant effect on the number of poor people in Central Java Province, GRDP per capita has a negative and significant effect on the number of poor people in Central Java Province and the number of unemployed Positive and significant to the number of poor people in Central Java Province. Puspandika's (2007) findings show that the most influential factor on human development is the real expenditure per capita, whereas GRDP per capita has no significant effect on human development. Between economic growth and human development there is no causal relationship, but the correlation between the two is positive. This finding also confirms that high economic growth does not directly improve the quality of life of the community or the Human Development Index (IMPM) of a region / region.

The above explanation can be understood that a correlation between available employment will ultimately increase household incomes that allow it to finance the quality improvement of family members. Improved human quality on the other hand will have an impact on the quality of labor, which in turn will affect the level and quality of economic growth. Briefly it can be said that growth can, (but not automatically) influence employment, on the demand side (creating jobs) and supply side (improving labor quality). In other words, theoretically, economic growth plays an important role to increase employment.

\subsection{Direct Sector Primary Influence On Human Development Index}

The result of statistical analysis shows that the direct impact of the primary sector on HDI in North Maluku Province is positive, meaning that if there is an increase of 10 percent growth in primary sector (X1) will increase the Human Development Index (Y2) by 26.1 percent. Real facts in North Maluku Province to date, the primary sector is a sector that is still dominant in absorbing labor. The distribution of labor force according to 
business field shows the sector which absorbs the most labor force is Agricultural Sector, in 5 years average absorb $55,1 \%$ of labor force, followed by Service Sector of Society $17,42 \%$, Trade Sector equal to $11,98 \%$, Transportation, Warehousing and Telecommunication sectors 5.81\%, Construction Sector 3.93\%, Manufacturing Processing 2.6\%, Mining and Quarrying 2.1\%, Financial Sector, Electricity, Water and Gas Procurement Sector Each below $1 \%$.

These results reinforce the findings of Sasana (2009) research in Central Java that absorbed labor has a positive and significant impact on the welfare (HDI) of the community. Thus, the absorbed Workforce has a direct effect on the welfare of society, which means that any increase in absorbed labor will increase the welfare of the people. The same result proved Saputra (2014) that independent variables of real GRDP and the price of Capital in agriculture significantly positively affect the employment absorption. The increase in real GRDP and Capital in agriculture will increase employment, and it is expected that with the increase of employment will reduce the adaptation and improve the Human Development Index (IMP) in Lampung Province.

According to Kuznet in Todaro (2003: 99) describes economic growth is a long-term capacity increase of the country concerned to provide a variety of economic goods to the population. The increase in capacity is determined by technological, institutional, and ideological advances or adjustments to the demands of existing circumstances. Todaro (2003: 92) conveyed there are three main factors or components in the economic growth of each country. The three factors are: (1) Capital accumulation, covering all forms or types of new investments invested in land, physical equipment, and capital or human resources. (2). Population growth, which in turn will increase the number of labor force; (3). Technological advances, in the form of new ways or improvements to old ways of dealing with jobs.

Above mentioned shows the existence of the relationship of causality of economic growth provides greater opportunity to the state or government to meet the basic needs of its people. However, the extent to which these needs are met depends on the ability of the state or government to allocate economic resources between communities and the distribution of income and opportunities for employment. Economic growth is also a major means for the welfare of society through human development which empirically proves to be a necessary condition for human development. In this case employment is the main bridge connecting economic growth and human capability improvement (UNDP, 2009). In other words, what is needed is not merely growth but quality economic growth in the sense of siding with the workforce.

\subsection{Direct Sector Secondary Influence on Human Development Index}

The results show a positive direct effect of the secondary sector on Human Development Index (IPM) in North Maluku Province, which means that if there is an increase of 10 percent of the secondary sector, it will improve the improvement of human development index in North Maluku Province by 80.6 percent. In North Maluku Province secondary sector ranks third in terms of its contribution to the absorption of labor. Trade Sector at $11.98 \%$, Transportation, Warehousing and Telecommunication Sector at 5.81\%, Construction Sector 3.93\%, Manufacturing Processing 2.6\%, Mining and Quarrying 2.1\%.

Theoretically, the economic growth achieved by a region, is the accumulation of the growth of all sectors achieved (primary sector, secondary and tertiary). According to UNDP, economic growth as the main vehicle for human development in order to take place on an ongoing basis. In improving the purchasing power of one of the businesses that must be done is to create the widest possible employment opportunities and need to be given ease in doing his business. For that research make five utilization of the land as decision variable. After going through the identification of the linkage of land use, the five land uses are used as decision variables, because of their relation to the existing economic sector. If from the five land use has been known that land use that will become a leading and progressive sector to provide economic growth, the government will further prioritize development of land use and its activities to the superior and progressive sectors.

Research conducted by Arham (2014), Fiscal Decentralization Policy, Sectoral Shift, and Inequality of Regencies / Municipalities in Central Sulawesi. The study finds that fiscal decentralization policies can encourage sector shifts, where the role of the primary sector is likely to decline, resulting in an increase in the role of the secondary and tertiary sectors during the implementation of regional autonomy. Thus the fiscal decentralization policy can create a change of economic structure in Central Sulawesi. The fiscal decentralization policy encourages increased inequality between districts in Central Sulawesi during the study period.

Harahap (2012), Analysis of sectoral developments in regional economic development activities in Langkat Regency. Based on GRDP at constant prices in 1993 shows that agricultural sector is still a top priority in Langkat District's economic sector contribution in 2000. The sectoral economic development of per capita GRDP shows that the variables of the primary production sector of the secondary production sector and tertiary production sectors are proven to have influence and Significant to PDRB per capita in Langkat Regency with 95\% 
confidence level.

For the primary production sector is the largest sector in the revenue PDRB so need to be increased again and developed through intensification and extensification in the field of agriculture by the relevant agencies and the Government. Similarly, the secondary production sector and the tertiary production sector are expected to replace the primary production sector in the future by facilitating the capitalization, production business facilities, educational training and the assistance of sectoral policies to create employment opportunities and income levels.

Sri Wahyuni Mustafa (2014), Private Investment Effect, Regional Expenditure and Consumer Price Index Against Manpower Absorption of Tourism Industry Through Output of Trade Sector And Other Service Sector In South Sulawesi Province. Based on the results of the analysis in this study, there are several things that need to be concluded that private investment has a positive and significant impact on the absorption of tourism sector workers through the output of trade and other services sectors. Tourism sector expenditures have a positive and significant impact on the absorption of tourism sector labor through the output of trade and other services sectors. The consumer price index does not have a positive and significant effect on the absorption of tourism sector labor through Output of Trade Sector and Other Service Sectors.

Development policy in each regency / city will be different, especially policy in the field of economic development (investment and economic growth), and employment (employment), but the ultimate goal is the same that is improving people's welfare. The facts encountered are the index of human development in national and provincial level is still low, that is still in the category of Medium Human developtment. The relatively low achievement of the human development index means there has been a problem in the implementation of economic development.

\subsection{Direct Sector Tertiary Influence on Human Development Index}

Statistics show that the direct effect of the tertiary sector on the Human Development Index / HDI is positive as indicated by the regression value of varied 0.827 which means that if there is a 10 percent increase in growth in the sector it will increase the growth rate of 82.7 percent in North Maluku Province. Real conditions in North Maluku Province tertiary sector ranked second after the primary sector. This sector grew $17.42 \%$.

Dornbusch, Fischer, and Startz, 2001 state that national output (as a representation of economic growth symbolized by Y) is a function of physical capital, labor and technological progress achieved. An important factor influencing the procurement of physical capital is investment, in the sense that high economic growth is expected to have a positive impact on the level of employment. An important factor influencing the procurement of physical capital is investment. Output will also increase if there is progress in technological progress indicated from the increase of production factors above. Therefore, the growth of the national economy can be derived from the growth of inputs and the development of technological progress which is also called the total growth factor of productivity, which in the end the quality of development of a State or region will be measured from how much the ability of the government in utilizing its resources to show justice The welfare of its people.

The above findings are in line with the results of the Puspandikan (2007) study which found that the GRDP variable had no significant effect on human development. This shows that between economic growth and human development does not have a significant relationship. Ability in meeting the needs of the workforce, is determined by how much revenue it receives, in addition to the type of work each workforce.

The tertiary sector which is more dominated by businesses in the service sector is currently growing quite well. In North Maluku Province the development of the tertiary sector also indicates sufficiently dominant pens, and is able to absorb $17.42 \%$ of employment, in 2014. Lee Jong Hwa's study on the relationship between economic growth and human development in the Republic of Korea period (1945-2002) The picture that between the two indices has a fairly close relationship. This means that economic growth will make human development better, and vice versa as a result of improving the quality of human beings in the long run will make the economic performance will increase.

Ranis (2004) states that human development is the impact of human capital development. While the improvement of human capital itself can not be separated from the improvement of economic performance. In other words, economic performance and its impact on human development and vice versa are strong links.

The link between economic growth and human development can be divided into two lines by Ramirez, et al (1998). The first point, economic performance affects human development, particularly through household and government activities, in addition to civilian roles such as through community organizations and non-governmental organizations. The second line, from human development to economic growth. High levels of human development will affect the economy through increased population capability, and the consequences are 
also on their productivity and creativity. Education and health of the population greatly determines the ability to absorb and manage the sources of economic growth both in relation to technology to the institutions that are essential for economic growth.

The above explanation can be understood that when the economic improvement of a country and or region, which is reflected by the increasing contribution of each sector, both the primary sector; Secondary and tertiary sectors, ideally followed by open employment and increased employment, and ultimately those who have gained employment can meet their minimum needs, thereby improving the quality of community life, or specifically concluding that the Human Development Index becomes more qualified.

\section{References}

Arsyad, L. (1999). Economic Development, fourth edition. STIE YKPN, Yogyakarta.

Bello, T. (2003). Attacking unemployment hurdles in the fragile economies of the Sub-Saharan Africa: the experience of Nigeria. A Paper Presented At the-Economics for the Future-conference; On The Occasion Of the Celebration of 100 Years of Cambridge Economics; Cambridge, United Kingdom September.

Calmfors, L., \& Holmlund, B. (2000). Unemployment and economic growth: A partial survey. Swedish Economic Policy Review, 7, 107-153.

Driffill, J., \& Schultz, C. (1992). Wage Setting and Stabilization Policy in a Game with Renegotiation. Oxford Economic Papers, New Series, 44, 440-459. https://doi.org/10.1093/oxfordjournals.oep.a042057

Ede, C. E., Ndubisi, E. C., \& Nwankwo, C. A. (2013). Tackling unemployment through private sector. International Journal of Innovation Research in Management, 2(2), 41-52.

Ezie, O. (2012). Youth unemployment and its socio-economic implications in Nigeria. Journal of Social Science and Public Policy, 4, 112-119.

Fajana, S. (2000). Functioning of the Nigerian Labor Market. Labonfin and Company, Lagos.

George, E. O., \& Oseni, J. O. (2012). The relationship between electricity power and unemployment rates in Nigeria. Australian Journal of Business and Management Research, 2(2), 10-19.

Ghozali, I. (2006). Statistik Nonparametrik. Semarang: Badan Penerbit UNDIP

Ghozali, I. (2006). Structural Equation Modeling Metode Alternatif dengan Partial Least Square. Semarang: Badan Penerbit UNDIP.

Ghozali, I. (2008). Model Persamaan: Konsep dan Aplikasi dengan Program AMOS 16 Semarang: Badan Penerbit UNDIP.

Ghozali, I. (2011). Aplikasi Analisis Multivariate Dengan Program SPSS. Semarang: BP Universitas Diponegoro.

Ghozali, I., \& Fuad. (2008). Structural Equation Modeling: Teori, Konsep dan Aplikasi Dengan Program Lisrel 8.0. Semarang: Badan Penerbit UNDIP

Ghozali.,I. (2009). Aplikasi Multivariate Dengan Program SPSS. Badan Penerbit Universitas Diponegoro: Semarang

Gujarati, D. (2006). Dasar-Dasar Ekonometrika. Jakarta: Erlangga.

Gujarati, D. P. (2012). Dasar-Dasar Ekonometrika. Jakarta: Salemba Empat.

Mardiasmo. (2004). Public Sector Accounting. Andi Publisher. Yogyakarta.

Njoku, A., \& Ihugba, O. (2011). Unemployment and Nigerian economic growth (1985-2009). Proceeding of the 2011 International Conference on Teaching, Learning and Change. International association for teaching and learning (IATEL).

Walterskirchen, E. (1999). The relationship between growth, employment and Unemployment in the EU European economists for an alternative economic policy (tser network). Workshop in Barcelona, 16 to 18 September.

\section{Copyrights}

Copyright for this article is retained by the author(s), with first publication rights granted to the journal.

This is an open-access article distributed under the terms and conditions of the Creative Commons Attribution license (http://creativecommons.org/licenses/by/4.0/). 